\title{
IAMJ
}

INTERNATIONAL

AYURVEDIC

MEDICAL JOURNAL

Research Article

ISSN: 2320-5091

Impact Factor: 6.719

\section{CLINICAL EVALUATION OF THE NEPHROPROTECTIVE EFFECT OF POLY HERBO-MINERAL COMPOUND IN CKD}

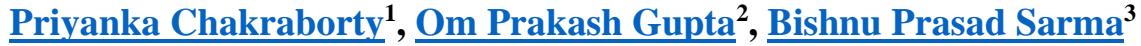

${ }^{1}$ PG Scholar, Department of Kayachikitsa, Government Ayurvedic College and Hospital, Jalukbari, Kamrup (M), Guwahati, Assam (India) Pin-781014

${ }^{2}$ Professor, Department of Kayachikitsa, Government Ayurvedic College and Hospital, Jalukbari, Kamrup (M), Guwahati, Assam (India) Pin-781014

${ }^{3}$ Professor, Department of Kayachikitsa, Government Ayurvedic College and Hospital, Jalukbari, Kamrup (M), Guwahati, Assam (India) Pin-781014

Corresponding Author: priyankachakraborty.604@gmail.com

\section{https://doi.org/10.46607/iamj1509082021}

(Published Online: August 2021)

Open Access

(C) International Ayurvedic Medical Journal, India 2021

Article Received: 30/07//2021 - Peer Reviewed: 10/08/2021 - Accepted for Publication: 11/08/2021

\section{Check for updates}

\section{ABSTRACT}

CKD (Chronic Kidney Disease) is now a worldwide health crisis. The present study focuses on the efficacy of the poly herbo-mineral compound in the nephroprotective effect in CKD. Consent from all the selected patients was taken before the study. Ethical clearance was accredited by the Government Ayurvedic college and hospital, Guwahati, Assam. The patients were given the trial drug $1 \mathrm{gm}$ twice daily after food with Tandulyodak $25 \mathrm{ml}$ and Punarnava panchanga kwath $25 \mathrm{ml}$ as anupana for 3 months. A marked improvement was found in eGFR, Serum Creatinine, Blood Urea and Urine Albumin levels. Satisfactory results were noted in chief complaints like urine output, oedema, nausea, vomiting and muscle cramps and Serum Uric acid level. No change was observed in Serum Sodium and Serum Potassium levels at the end of the course.

Keywords: Chronic kidney disease, poly herbo-mineral, anupana, Tandulyodak, Punarnava panchanga Kwath 


\section{INTRODUCTION}

In the entire lifespan of a human, the kidneys play a vital role in maintaining homeostasis. Obesity, hypertension, Diabetes mellitus and drugs are the major risk factors for renal dysfunction as of today.

CKD encompass a spectrum of different pathophysiological process associated with abnormal kidney function and progressive decline in glomerular filtration rate(GFR) along with hyper infiltration and hypertrophy of the viable nephrons. It leads to long term reduction of renal mass irrespective of the underlying aetiology. It is often symptomless in the early stages and gets detected when the disease starts deteriorating. Kidney disease is often claimed to be a "Silent disease" $^{[1][2]}$. In modern medicine, ACE inhibitors and $\mathrm{ARBs}$ are the drug of choice for $\mathrm{CKD}^{[1]}$. In progressive stages, the building up of innumerable toxins in the renal blood flow is characterised by Uremic syndrome leading to Vasculopathy. According to Ayurveda, CKD or Vrikka roga can be defined as an amalgamation of lakshan of several diseases like Rasa pradosaj vikar, Kaphaj sotha, Pandu, Mutrakriccha, Mutraghata, Prameha and its upadrava ${ }^{[3][4][5]}$. The dosha prakopak hetu like Nidanarthakara roga, Santarpanjanya, Apatarpanjanya and Ajeerna avastha leads to Agni dushti and therefore vitiation of Samana vayu, Pachak pitta and Ranjaka piitta occurs with the aggravation of Kledak kapha. The prakupita dosha gets sthansamshraya in Vrikka and mutrasaya through Vyan vayu leading to Srotadushti of dhatus, mala and oja which results in apana vayu vitiation ${ }^{[3][4][5]}$. This directs to the pathogenesis of Vrikka roga or CKD. Therefore, proper palliative treatment should be done with the Ayurveda as it has fewer side effects and has the potency of rejuvenating the viable nephrons. With all this in view, an attempt has been made to prepare a poly herbo-mineral compound ${ }^{[6][7][8]}$ and to evaluate its nephroprotective effect.

\section{AIM AND OBJECTIVES}

1. To evaluate the nephroprotective effect of the poly herbo-mineral compound in CKD

2. And, to find out the adverse effect of poly herbomineral compound (if any)

\section{MATERIALS AND METHODS}

Total numbers of 40 patients were registered for the Open labelled Interventional Clinical Trial from the OPD of Kayachikitsa, Govt. Ayurvedic College and Hospital, Ghy-14 based on the exclusion and inclusion criteria after receiving the ethical clearance certificate from the Institutional Ethical Committee of Government Ayurvedic college and hospital, Guwahati, Assam (ref. no. IEC/19, 20-216). The cases have been properly evaluated by taking detailed chief complaints and medical history and laboratory investigations with their written consent.

The poly herbo-mineral compound ${ }^{[6][7][8]}$ (EPSP) along with Tandulyodak ${ }^{[6][7][8]}$ and Punarnava panchanga $k w a t h$ as anupana was given. The fine powder of all the ingredients of the poly herbo-mineral compound was mixed in equal proportions in churna form and packed weighing 100gm each.

Table 1: Contents of the poly herbo-mineral compound

\begin{tabular}{|l|l|l|l|}
\hline SL. NO. & Drugs & Botanical Names & Parts used \\
\hline 1 & Ela & Elettaria cardamomum & Seeds \\
\hline 2 & Pashanbheda & Bergenia ligulata & Root \\
\hline 3 & Shilajit & Asphaltum punja-bianum & Whole \\
\hline 4 & Pippali & Piper longum & Dried fruit \\
\hline
\end{tabular}

Dose of EPSP: $1 \mathrm{~g}$ twice daily after food ${ }^{[6][7][8]}$

Dose of Tandulyodak: $25 \mathrm{ml}$

Dose of Punarnava panchanga kwath: $25 \mathrm{ml}$

Duration of the study: 3 months

Follow up interval: 1 month or if necessary

\section{Diagnostic Criteria ${ }^{2}$}

1. Abnormalities of kidney structure and/or function noticed for $>=3$ months.

2. Medical History and Clinical features: 
a) The present history of Diabetes mellitus, hypertension

b) History of urinary tract infection

c) Family history of Polycystic kidney disease, Diabetes mellitus, systemic hypertension

d) Drug history like the use of Non-Steroidal Antiinflammatory Drugs, Angiotensin-converting enzyme inhibitors, Angiotensin receptor blockers, Penicillamine, Anti-microbial (like Cephalosporins, Aminoglycosides, etc), anti-retroviral drugs, Proton pump inhibitors.

e) Dietic history like details of intake of calorie, protein, fat, sodium, potassium

f) Obstetric history like early pregnancy loss, pregnancy-induced hypertension

g) Chief complaints like low urine output, oedema, nausea, vomiting, loss of appetite, fatigue, abdomen bloating, breathlessness, muscle cramps

3. Investigations:

a) eGFR (CKD-EPI 2009 equation) [eGFR calculator app by National Kidney Foundation]

b) Serum creatinine

c) Blood urea

d) Serum uric acid

e) Haemoglobin

f) Serum sodium

g) Serum potassium

h) Fasting blood sugar - To rule out Diabetes mellitus

i) Postprandial blood sugar - To rule out Diabetes mellitus

j) Random blood sugar- To rule out Diabetes mellitus

k) Urine albumin

1) Ultrasonography (whole abdomen)- To detect underlying pathology in the renal region or intrarenal region.

m) ECG - To exclude the cardiac disease patients

A. Inclusion Criteria

1. Patients coming under the diagnostic criteria

2. Adult patients between 18 years and 70 years of age irrespective of sex, occupation, religion
3. Patients with and without dialysis

B. Exclusion Criteria

1. Patients below 18 years and above 70 years of age

2. Patients suffering from major diseases-

a. Coronary artery diseases (CAD)

b. Malignancy

c. Chronic liver disease

d. Ascites

e. Tuberculosis

f. Sexually transmitted disease

3. Pregnancy and lactating mother

\section{ASSESSMENT CRITERIA}

\section{Subjective Criteria}

a) Urine output

b) Oedema

c) Nausea

d) Vomiting

e) Loss of appetite

f) Fatigue

g) Abdomen bloating

h) Breathlessness

i) Muscle cramps

2. Objective Criteria

a) eGFR (CKD-EPI 2009 equation) [eGFR calculator app by National Kidney Foundation]

b) Serum creatinine

c) Blood urea

d) Serum uric acid

e) Haemoglobin

f) Serum sodium

g) Serum potassium

h) Urine albumin

\section{DATA ANALYSIS}

The data obtained were organised and then analysed using the arithmetic mean, standard deviation and paired t-test.

OBSERVATION AND RESULTS: Among 40 patients, 10 patients got dropout due to unavoidable causes. 30 patients' data have been procured successfully and data analysis are done. 
Table 2: Effect of Treatment on Chief complaints and associated symptoms of 30 CKD patients

\begin{tabular}{|l|l|l|l|l|l|l|l|l|l|}
\hline SL. & Subjective & \multicolumn{3}{|c|}{ Mean value } & \multicolumn{3}{c|}{ S.D } & t-value & p-value \\
\cline { 3 - 9 } NO & & BT & AT & BT-AT & BT & AT & BT-AT & & \\
\hline 1 & Urine output & 0.30 & 0.57 & 0.27 & 0.47 & 0.50 & 0.03 & 3.2474 & $<0.05$ and $>0.001$ \\
\hline 2 & Oedema & 0.90 & 0.60 & 0.30 & 0.96 & 0.86 & 0.10 & 2.7572 & $<0.05$ and $>0.001$ \\
\hline 3 & Nausea & 0.71 & 0.43 & 0.28 & 0.71 & 0.50 & 0.21 & 3.2863 & $<0.05$ and $>0.001$ \\
\hline 4 & Vomiting & 0.37 & 0.13 & 0.24 & 0.67 & 0.35 & 0.32 & 2.9709 & $<0.05$ and $>0.001$ \\
\hline 5 & Abdomen Bloating & 1.20 & 0.97 & 0.23 & 0.61 & 0.67 & 0.06 & 2.0414 & $<0.05$ and $>0.001$ \\
\hline 6 & Fatigue & 0.90 & 0.83 & 0.07 & 0.99 & 0.95 & 0.04 & 1.4392 & $<0.05$ and $>0.001$ \\
\hline 7 & Loss of Appetite & 1.00 & 0.90 & 0.1 & 0.53 & 0.55 & 0.02 & 1.7951 & $<0.05$ and $>0.001$ \\
\hline 8 & Breathlessness & 0.13 & 0.07 & 0.06 & 0.35 & 0.25 & 0.10 & 1.4392 & $<0.05$ and $>0.001$ \\
\hline 9 & Muscle cramps & 0.23 & 0.07 & 0.16 & 0.43 & 0.25 & 0.18 & 2.4083 & $<0.05$ and $>0.001$ \\
\hline
\end{tabular}

Table 3: Effect of Treatment on Pathological investigations on 30 CKD patients

\begin{tabular}{|l|l|l|l|l|l|l|l|l|l|}
\hline \multirow{2}{*}{ SL. NO } & \multirow{2}{*}{ Objective } & \multicolumn{3}{|c|}{ Mean value } & \multicolumn{3}{c|}{ S.D } & t-value & p-value \\
\cline { 3 - 9 } & & BT & AT & BT-AT & BT & AT & BT-AT & & \\
\hline 1 & eGFR & 18.63 & 25.2 & 6.57 & 20.66 & 23.43 & 2.77 & 4.0659 & $<0.001$ \\
\hline 2 & Serum Creatinine & 5.77 & 4.63 & 1.14 & 3.17 & 3.16 & 0.001 & 3.9218 & $<0.001$ \\
\hline 3 & Blood Urea & 94.36 & 81.46 & 12.9 & 43.08 & 34.96 & 8.12 & 2.2103 & $<0.001$ \\
\hline 4 & Serum Uric acid & 6.47 & 5.60 & 0.87 & 2.16 & 1.90 & 0.26 & 2.1689 & $<0.05$ and $>0.001$ \\
\hline 5 & Haemoglobin & 8.74 & 8.54 & 0.2 & 1.85 & 1.84 & 0.01 & 0.9281 & $>0.05$ \\
\hline 6 & Serum Sodium & 137.66 & 136.66 & 1 & 5.38 & 4.25 & 1.13 & 0.9266 & $>0.05$ \\
\hline 7 & Serum Potassium & 4.78 & 4.63 & 0.15 & 0.75 & 0.79 & 0.04 & 0.9208 & $>0.05$ \\
\hline 8 & Urine Albumin & 2.10 & 1.47 & 0.63 & 0.96 & 1.01 & 0.05 & 5.877 & $<0.001$ \\
\hline
\end{tabular}

\section{DISCUSSION}

A statistically significant result was observed in all the chief complaints and associated symptoms. Thus, the treatment has a moderate effect on oedema, urine output and nausea. A very mild effect has been observed on vomiting, abdomen bloating and Muscle cramps. The treatment has no effect or change in the loss of appetite, fatigue, and breathlessness. A highly significant result was noted in the eGFR, Serum Creatinine, Blood Urea and Urine Albumin level. A significant result was noted in Serum Uric acid. There was no significant result seen in Haemoglobin, Serum Sodium and Serum Potassium level but, the mean difference of before treatment and after treatment showed a minimum change and the treatment showed no response on them. Therefore, the highly significant result shows that the treatment has a beneficial effect as nephroprotective and improving kidney functions.

\section{Probable Mode of Action}

Ela has anuloman property and mutrajanan, therefore, it acts as bastisodhana. Pashanbheda act as mutravirechan. Due to laghu, ruksha and tikshna guna, the aggravated kapha gets alleviated and the avarana of vata mainly Udan and apan vayu gets removed. Due to the Sheeta virya of Ela, Pashanbheda, Shilajit, the aggravated kapha and pitta gets subsided and therefore the Dhatwagni gets ignited. Whereas due to katu vipaka, it also has mild action on Jatharagni ${ }^{[9]}$. Because of the Rasayana property of Shilajit and Pippali, it acts as srotasodhan, rejuvenates the deranged srota and clears the abaddha meda ${ }^{[9]}$. EPSP has less action on Jatharagni but more on Dhatwagni. Therefore, it has mild action on nausea, vomiting, abdomen bloating and loss of appetite and highly significant action on eGFR, Serum Creatinine and Urine Albumin. Anuloman, mutrajanan and mutravirechaniya properties present in the trial drug help in correcting the low urine output and pedal oedema. According to various researchers, Ela 
(Elettaria cardamomum) has a Renal protective effect $^{[11]}$; Pashanbheda (Bergenia ligulata) has Free radical scavenging activity, Anti-diabetic and Diuretic activity ${ }^{[12]}$; Shilajit (Asphaltum punja-bianum) has antioxidation and immuno-modulatory effect ${ }^{[13]}$; Pippali (Piper longum) possess Vasodilator effect, Blood pressure-lowering effect and Immuno-modulatory effect $^{[14]}$. Tandulyodak has a soothing effect due to its sheeta virya ${ }^{[10]}$. The laghu and ruksha guna of Punarnava helps in kapha-vatahara ${ }^{[9]}$; sheeta virya helps in nourishing the dhatwagni and the katu vipaka helps in the digestion process. It has a Renal protective effect with antioxidant propert ${ }^{\text {ies [15] }}$.

\section{Adverse reaction/Side effects}

No advance or untoward side effect was observed in any of the patients. But, if the dose of the Tandulyodak is less than $25 \mathrm{ml}$ or "EPSP" taken alone, then the burning sensation over the chest and epigastric region can be experienced.

\section{CONCLUSION}

This study is working on focussing on the Ayurvedic management of Nephropathy holistically. In a nutshell, the following points and facts regarding the study and can be stated that the poly herbo-mineral compound showed a very impressive response. Most of the cases responded to the treatment. A satisfactory reduction in the signs and symptoms have been noticed from the treatment. A marked improvement has been observed in laboratorical investigations. Therefore, an inference can be drawn that the poly herbo-mineral compound "EPSP" with Tandulyodak and Punarnava panchanga kwath as anupana has anabolic, anti-inflammatory, anti-oxidative effects and helps in reducing albuminuria. Thus, all the three compounds together are said to have promise nephroprotective effect in the management of CKD. The dose of the trial drug may be enhanced to get a better result. A large number of patients or sample size should be taken, and treatment should be made for a longer duration of time.

\section{REFERENCES}

1. Jameson J Larry, Loscalzo Joseph. Harrison's Nephrology and acid-base disorder, $2^{\text {nd }}$ edition. MacGraw Hill Professional, 2013;22-336.

2. Turner Neil et al. Oxford textbook of clinical nephrology, $4^{\text {th }}$ edition. Oxford University Press, 2016;7391195.

3. Vagbhata. Commentator Kaviraj Atridev Gupta. Ashtanga Hridayam. Chaukhambha Prakashani, 2018.

4. Agnivesha. Charaka Samhita, Savimarsha vidyotini, Edited by Pandit Kashinath Shastri, Dr Gorakhnath Chaturvedi. Chikitsa sthan. volume 2, Chaukhambha Prakashani

5. Sushruta. Sushruta Samhita. Ayurveda Tattwa Sandipika. Edited by Kaviraja Ambikadutta Shastri. Chaukhambha Prakashani, 2015.

6. Sri Chakrapanidatta. Chakradatta, Hindi commentatory by Dr Indradev Tripathi. Mutrakricha chikitsa, chapter 32. Chaukhambha Prakashani ;207

7. Shri Govind Das. Bhaisajya Ratnavali. Edited by Shri Kaviraja Ambikadatta Shastri. volume 2, Mutrakricha chikitsa, chapter 35. Chaukhambha Prakashani, 702

8. Shri Govind Das. Bhaisajya Ratnavali. edited by Shri Kaviraja Ambikadatta Shastri. Volume 2. Prameha chikitsa, chapter 37. Chaukhambha Prakashani, 725

9. Acharya Priyavrata Sharma, Dravyaguna vijnan, volume 2

10. Shri Govind Das. Bhaisajya Ratnavali. edited by Shri Kaviraja Ambikadatta Shastri. Volume 1, Grahaniroga chikitsa, Chapter 8, Chaukhambha Prakashani, 243

11. Elkomy Ashraf, Aboubakr Mohamed and Elsawaf Noha. Renal protective effect of cardamom against nephrotoxicity induced by gentamicin in rats. BVMJ. December 2015; VOL. 29(Issue 2):100-105

12. Gurav S.S, Gurav N.S. A Comprehensive ReviewBerginia ligulata-a controversial clinical candidate. Int. J. Pharm. Sci. Res. 2014; Vol. 5(Issue 5):1630-1642

13. Ghosal Shibnath. Chemistry of Shilajit, an immunomodulatory Ayurvedic rasayan. Pure Appl. Chem. 1990; Vol. 62(Issue 7):1285-1288

14. Husain Intasar Taqvi Syed, Shah Jabbar Abdul, Gilani Anwarul Hassan. Blood pressure-lowering and vasomodulator effects of piperine. J. Cardiovasc. Pharmacol. November 2008; Volume 52(Issue 5):452-458

15. M Pramila Padmini, J Vijay Kumar. An experimental study of biochemical and histopathological study on gentamicin-induced renal failure in Albino rats and the effectiveness of Punarnava on reversal of Renal 
damage. J. Med. Dent. Sci. September-October 2013; volume 9(Issue 6):17-21

\begin{abstract}
Abbreviations
CKD- Chronic Kidney Disease, ACE- Angiotensinconverting enzyme, ARB- Angiotensin II receptor blocker eGFR- estimated Glomerular Filtration Rate
\end{abstract}

\title{
Source of Support: Nil
}

\section{Conflict of Interest: None Declared}

How to cite this URL: Priyanka Chakraborty et al: Clinical Evaluation Of The Nephroprotective Effect Of Poly HerboMineral Compound In CKD. International Ayurvedic Medical Journal \{online\} 2021 \{cited August 2021\} Available from: http://www.iamj.in/posts/images/upload/1698 1703.pdf 